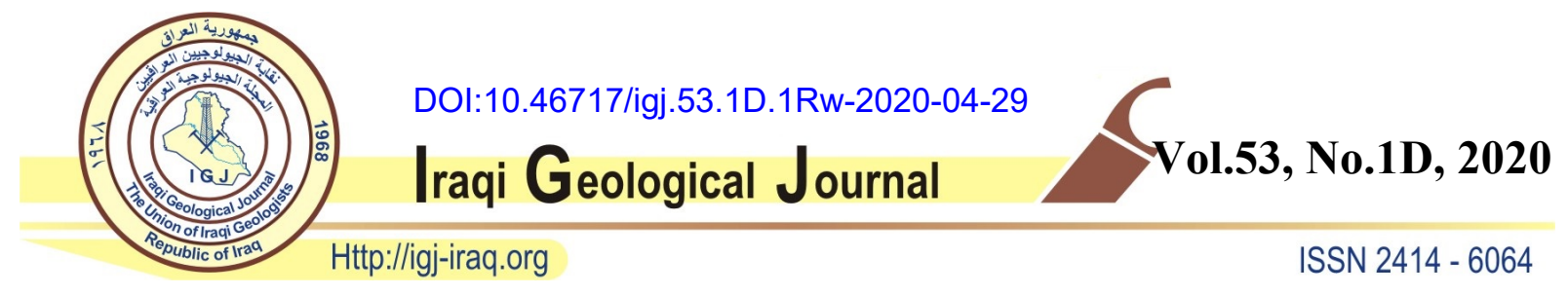

\title{
RESERVE ESTIMATION OF LATE MIOCENE INJANA CLAYSTONE BEDS FOR PORTLAND CEMENT AND BRICK INDUSTRY, MIDDLE OF IRAQ
}

\author{
${ }^{1}$ Ali M. Awad and ${ }^{1}$ Salih Muhammad Awadh* \\ ${ }^{1}$ Department of Geology, College of Science, University of Baghdad, Baghdad, Iraq \\ *Email: salihauad2000@yahoo.com \\ Received: 21 February 2020; accepted: 18 March 2020
}

\begin{abstract}
The aim of this study is to evaluate the Late Miocene clay for manufacturing cement and bricks (ordinary and perforated) as an alternative to the recent clays from the agricultural land that are used typically for agricultural purposes. The claystone beds of the Injana Formation (middle of Iraq) was studied over 18 exposed sections, and sampled by using the trench sampling method. Two industrial beds were recognized as upper and lower beds. The upper industrial bed has thicknesses varies from $1.0 \mathrm{~m}$ to $4.5 \mathrm{~m}$, with an average of about $3.16 \mathrm{~m}$ and area covers $576 \times 106 \mathrm{~m}^{2}$. The lower claystone bed ranges from $2.0 \mathrm{~m}$ to $4.0 \mathrm{~m}$ with an average of about $2.7 \mathrm{~m}$, and area $453614 \times 103 \mathrm{~m}^{2}$. The clay reserve was defined by a total area 1,029,614x103 $\mathrm{m}^{2}$, total volume 3,044,917,800 $\mathrm{m}^{3}$, bulk density $1.68 \mathrm{gm} / \mathrm{cm}^{3}$, and average of compressive strength $154 \mathrm{Kg} / \mathrm{cm}^{2}$. The total volume of overburden and inner burden is $1364676 \times 10^{3} \mathrm{~m}^{3}$ with stripping ratio of the overburden 0.3 . The clay reserve was classified as a C1 class based on the Russian system, with an estimation of 5,663,547,108 tons based on GIS method and 5,694,522,037 tons calculated by triangles method.
\end{abstract}

Keywords: Reserve estimation; Portland cement: Brick; Injana claystone

\section{INTRODUCTION}

The reserve estimate reveals the economic effectiveness of investigation and provides with data necessary to assess the quality of the work of exploration geologists (Kreiter, 1968). The geological exploration of natural resources is very expensive; however, it opens new challenges and opportunities. The geological investigation follows a series of multidisciplinary activities: reconnaissance, exploration, prospecting, and economic mining. The investigation concept looks for a package of unique stratigraphic age of promising favorable rocks (Haldar, 2018). In Iraq, topsoil is used as a raw material in the manufacture of bricks and cement, these soils are suitable for cultivation and its depletion in these industries causes environmental degradation and reduction of green areas (Awadh and Abdullah, 2011). According to this concept, this study 
is targeted old and not superficial clays, so it was chosen the clay beds of Injana Formation (Late Miocene) exposed in Tar Al- Najaf, Tar Al-Sayyed, and several small isolated hills located to west nearby (Fig. 1). The reserve of claystones suitable for the cement and bricks manufacture was estimated based on data collected from fieldwork at 18 sites. Several factors control reserve calculations; these are the area of certain material, thickness of the industrial bed, sampling method, concentration the certain material and its chemical characterization, bulk density, volume and weight of overburden (Wellmer et al., 2008). The Russian, British, American, and the Joint Ore Reserve Committee (JORC), the most globally famous reserve estimation systems. However, in this paper, have been applied and discussed only the Russian system, due to its high reliability (Al-Auweidy, 2013).

The study aims to 1) evaluate the Injana claystone for using in the manufacture of cement and bricks as a suitable raw material instead of the clay that is taken from the recent soils; 2) estimate the clay reserve by using triangle and geographic information systems (GIS) methods.

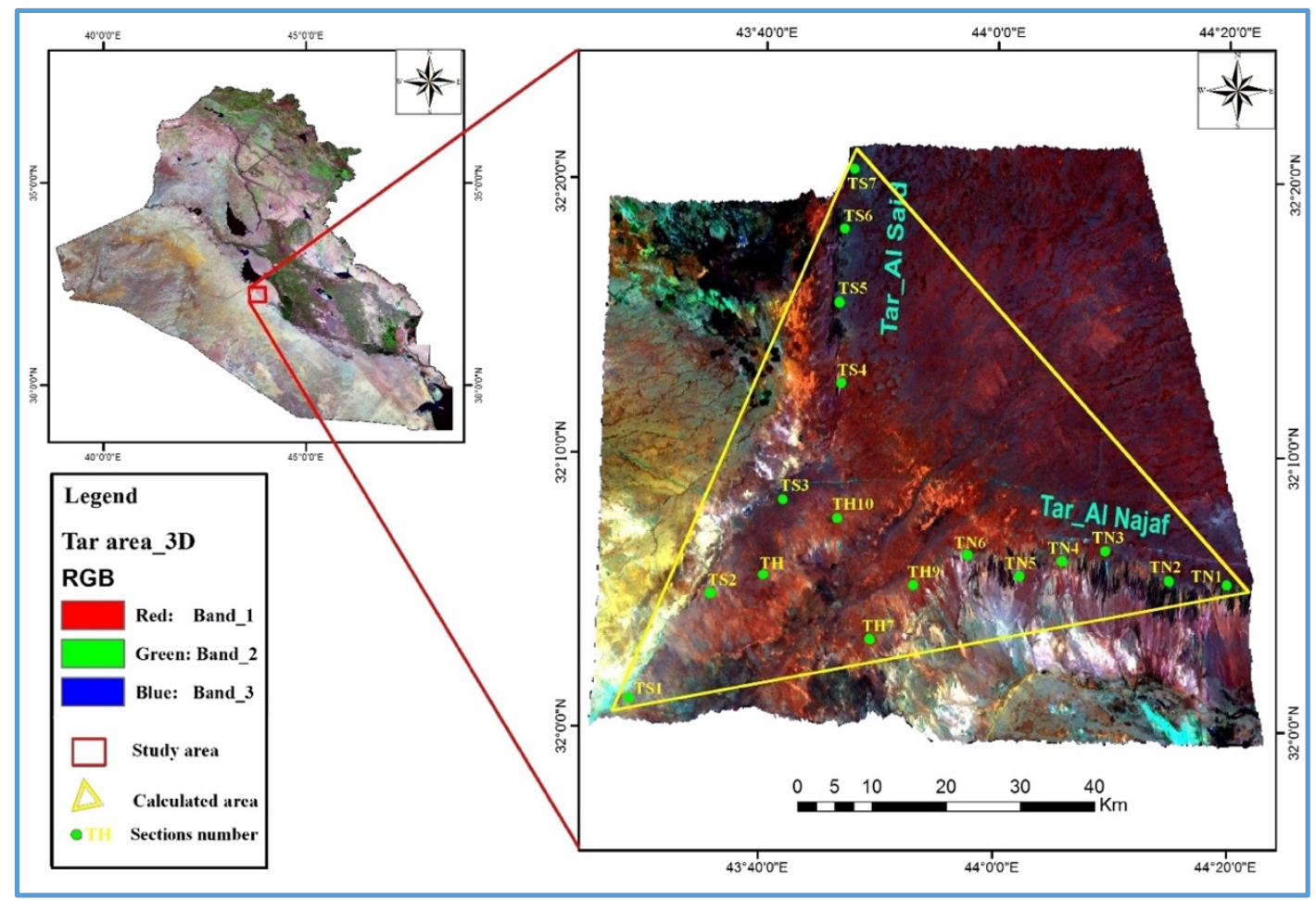

Fig. 1. Landsat satellite image showing the studied sections in the study area

\section{MATERIALS AND METHODS}

The quantitative evaluation of claystone (industrial bed) was determined based on the results of chemical analysis and geotechnical evaluation. The Injana Formation (Late Miocene) consists of two beds of claystone that nominated as an industrial bed composing mainly of, claystone, brown to light brown in color, tough to medium tough. Quaternary sediments and Dibdibba Formation represent the overburden. The industrial bed is exposed to the surface in 
several sites, especially in the southern part of the study area, but it mostly hides under the overburden (Fig. 2). The control factors for the determination of reserves for the industrial purposes are the area and thickness of interested bed, bulk density, the thickness of the overburden, and stripping ratio. The reserve estimation of claystone is a process of volumetric and weight calculation of the claystone sediments quantity in the study area. The volume estimation of these sediments can be computed by determining the dimension of claystone bed, calculating of the thickness and the bulk density of that area (Al-Atia, 2001). The reserve estimation was computed depending on the following equation according to Moon et al., (2006):

$T=A \times A v$ thickness $x(B D)$

Where:

T: Tonnage (tons)

A: Area of industrial bed $\left(\mathrm{m}^{2}\right)$.

Av: Average thickness of the industrial bed of area (m).

BD: bulk density $\left(\mathrm{Kg} / \mathrm{m}^{3}\right)$.

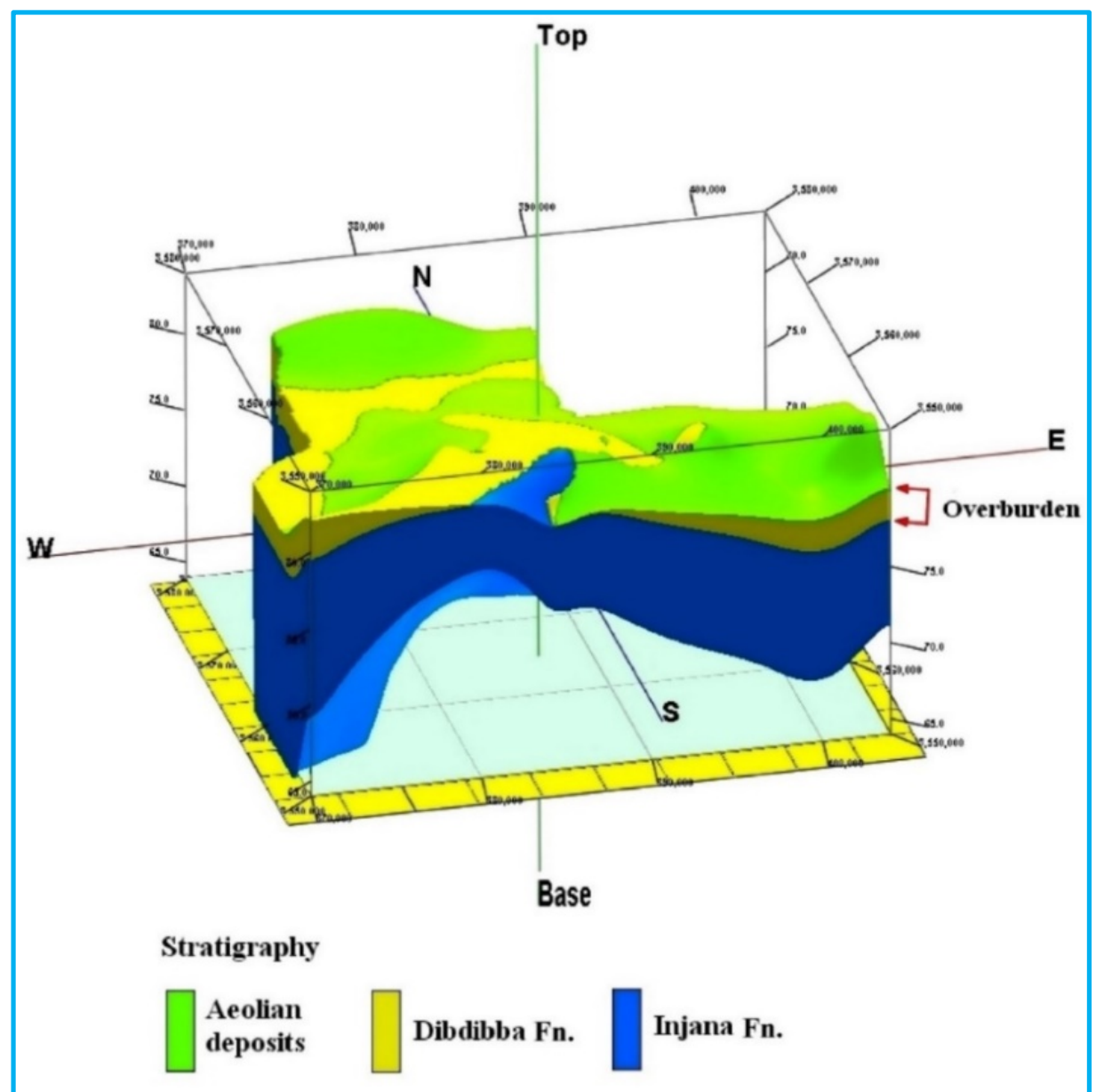

Fig. 2. Stereo- sequence stratigraphy of the Quaternary sediments, Dibdibba Formation (overburden bed) and Injana Formation (industrial bed) of the study area 
There are four systems (Russian, British, the Joint Ore Reserve Committee (JORC), and American) that are internationally used for the estimation of the reserve (Taylor, 1994). The current study focuses on the Russian system because of its ease of application and accurate system (Al-Auweidy, 2013 and Ali et al. 2014).

The Russian system was introduced by the Soviet Academy of Sciences in 1933 and revised in 1953. Under this system, mineral sediments were classified into four main categories (A, B, C1 and C2) (Al-Atia, 2001). The Russian system is relatively simple, and the Iraqi Geological Survey adopted this system in Iraq. The concepts of these categories are explained as follows:

\section{A) Category-A reserve}

This category is only achieved during actual mining and exploitation of the deposit. Reserve estimation of this category should be based on closely spaced observation points, measurements, and sampling. Reserve estimation can be obtained from trenches, pits, boreholes, shafts, tunnels and other mining works. Detailed production plans and mine designs are made at this category of reserve estimation. The maximum allowable error in all parameters of estimation is $10 \%$, which should be tested by geo-statistical means (Al-Bassam and AlKhafaji, 2012).

\section{B) Category-B reserve}

This is an advanced stage of economic reserve estimation as far as the confidence level and reliability of data related to the various aspects of reserve estimation. The results of this stage of exploration are used to prepare a preliminary mining design, technological treatment of the raw material, feasibility studies, and for estimating mining and technological investment. This category of reserve estimation is essential applied for planning the development of sediments. It requires a relatively high accuracy of estimation based on actual field observations and measurements. These are obtained from trenches, boreholes, pits and in complicated sediments from mine workings. The sites of investigation, sampling and measurement are spaced so closely as to provide an accuracy of $10-30 \%$ in all parameters of reserve estimation (AlBassam and Al-Khafaji, 2012). The geologic character should be very well defined, as well as the size, shape, depth and mineral content.

\section{C) Category-C1 reserve}

This category of economic reserve estimation is based on a higher density of documentation points including boreholes, trenches, pits and outcrops. The initiation of this stage of work depends on data evaluation and decision taken at the end of the previous stage (i.e. at the end of Category -C2). Fairly accurate and reliable data are required at this stage on thickness, shape and extension of the deposit, thickness of overburden, chemical and physical specifications of 
the deposit, hydrogeological conditions, mining conditions and technological treatment. The confidence from this information should be enough to plan long-term development of the deposit and should serve as a base for more detailed exploration stages. The reliability and error margin of these estimates should be tested by geostatistical means and should be in the range 30-50\% (Al-Bassam and Al-Khafaji, 2012).

\section{D) Category-C2 reserve}

It is the in situ part of an Identified Resource, which have been demonstrated by actual field observation, measurement and sampling to suite minimum physical and chemical criteria required for current or future mining and industrial production practices. Quantitative estimates are based on widely spaced documentation points which may include boreholes, trenches, pits, outcrops, etc. In addition, results of geological, geophysical and geochemical surveys should be used (if available) to complement the estimates. A limited number of samples are collected for chemical, mineralogical and technological examinations. The information provided by such category is of preliminary nature, concerning the extension, thickness, shape, mineralogical and chemical composition, overburden, host rock composition and suitability for industrial uses. The acceptable error in the estimates of all reserve parameters of this category is (50-70) \% (AlBassam and Al-Khafaji, 2012).

The reserve estimation of the cement and brick raw material (claystone) in this study is computed according to different methods such as those of Mendelsohn (1980), Al-Atia (2001), Wellmer, et al. (2008), Al-Bassam and Al-Khafaji (2012). The methods used in the current study for the reserve estimation of claystones are triangle and GIS methods, because they are more accurate and very easy to implement than other traditional methods.

\section{A. Triangles Method}

It is based on dividing the area into triangles by connecting the adjacent sections with straight lines. The area of each triangle is mathematically computed. The study area is an isosceles triangle with dimensions $34 \times 34$ × $36 \mathrm{~km}$. Each triangle represents three sections. The triangle sides are unequal and the angle degree unequal $60^{\circ}$; for this case, the correction factor is recommended to correct the thickness of claystone bed in each triangle based on Mendelsohn (1980), Al-Atia (2001), Wellmer et al., (2008), and Al-Bassam and Al-Khafaji (2012). It was achieved as follows:

Correction factor (C.F.) $=\frac{\text { Angle of the triangle peak }}{60^{0}}$

The reserve (tonnage) was calculated by the equation below:

$\mathrm{R}($ ton $)=\mathrm{A}\left(\mathrm{m}^{2}\right) \times \mathrm{ACT}(\mathrm{m}) \times \mathrm{BD}\left(\mathrm{g} / \mathrm{cm}^{3}\right)$ 
A: The total area, ACT: Average of Corrected Thickness, BD: average of Bulk Density (AlAtia, 2001). The average of corrected thickness of each triangle in the study area was calculated by the following equation:

$\mathrm{ACT}=\frac{\mathrm{A}(\mathrm{T} 1 \times \mathrm{F} 1)+(\mathrm{T} 2 \times \mathrm{F} 2)+(\mathrm{T} 3 \times \mathrm{F} 3)}{\mathrm{n}}$

Where: ACT: Average of corrected thickness of triangle (m). T1, T2 and T3: Thickness of the industrial bed in sections. F1, F2 and F3: Correction factors for each triangle. $\mathrm{n}$ : is a number of sections and which equal 3.

The triangle area is in unit of $\mathrm{m}^{2}$, depending on the equation below:

$\mathrm{A}=1 / 2 \mathrm{~B} \times \mathrm{H}$

Where:

A: The area of triangle, B: Base of triangle and $\mathrm{H}$ : Height of triangle.

The area in this method is calculated by the following equation:

$A(m)^{2}=U+L$

Where:

A: The total area of both industrial bed, U: The total area of upper industrial bed, L: The total area of lower industrial bed

\section{Geographic Information Systems (GIS)}

A Geographic Information System (GIS) offers great potential as a tool for the analysis of geochemical data for the mineral exploration applications. GIS does not only display routine geochemical data, but also provides a range of spatial analysis tools through which data can be queried, processed, visualized and analyzed (Janipella et al., 2019). The use of computer in mineral exploration in the past twenty years has dramatically changed the way implement exploration targeting (Carranza, 2009). This is particularly true in the last five years where computer technology and global positioning system (GPS) have evolved to the stage where it is possible to digitally locate, accurately store, visualize and manipulate geological data at the scale of a mineral system. These tasks are commonly performed using a GIS, which has become an important tool for a geologist as his hammer (Partington, 2010). Therefore, GIS method was used to calculate the area of the studied area as it is more accurate than conventional methods.

The positive area was calculated by GIS method (ArcGIS tool), which used to obtain the coverage area. In this method, we have been drawn a polygon that represents the investigated area depending on certain data, collected from the investigated area. These data are XY coordinates of sections, total depth, and maps in image formula. Finally, WGS1984 UTM Zone $38 \mathrm{~N}$ coordinate system was used to calculate the investigated area (Fig. 3). 


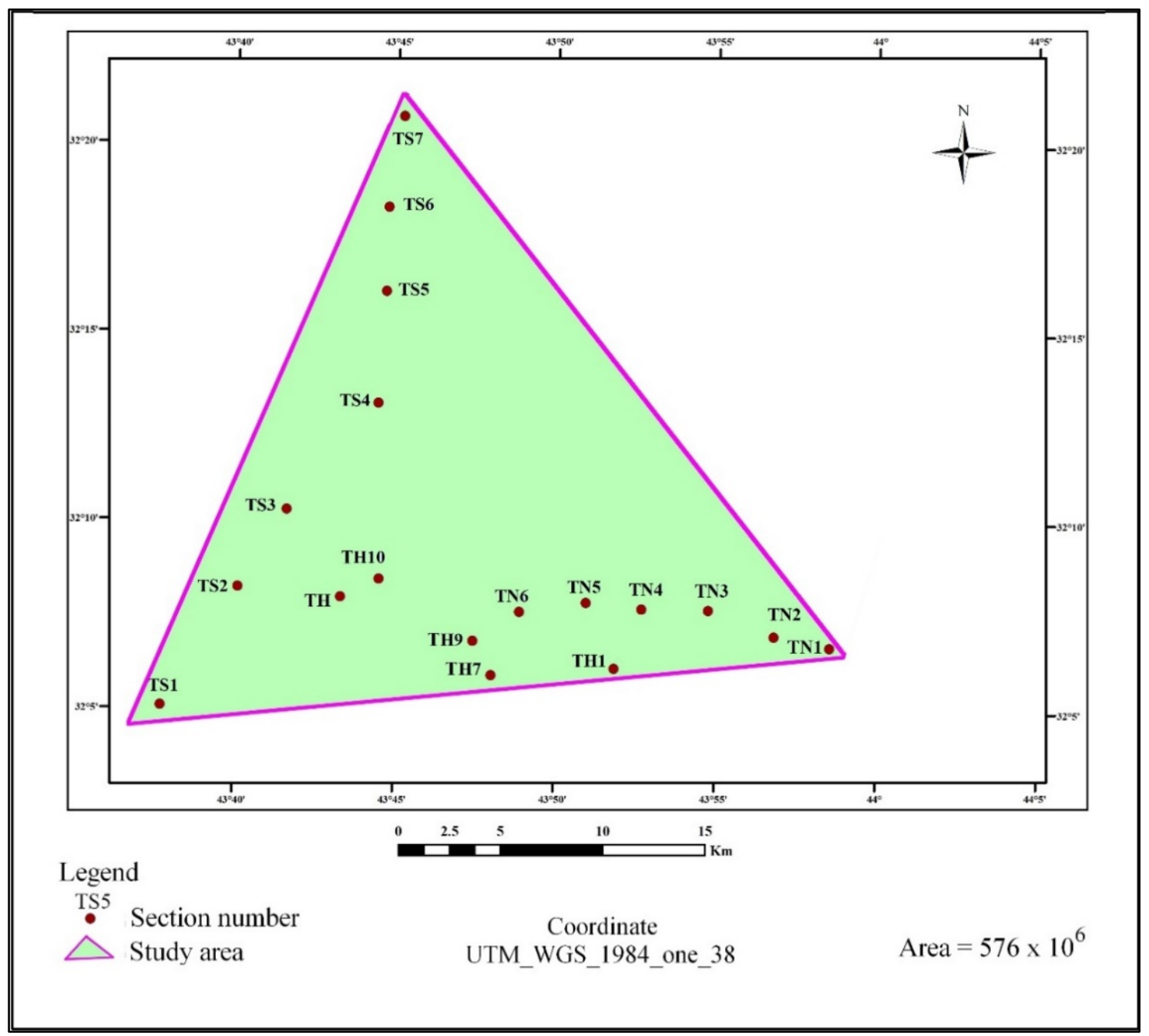

Fig. 3. Reserve calculation by the GIS method

\section{RESULTS}

The quantitative evaluation of the study area includes two major parts as follows:

\section{Quantitative Evaluation of The Industrial Bed (Claystone)}

The calculation of industrial bed (claystone) reserve based on data collected from eighteen sections (Fig. 4). The industrial bed in the investigated area consists of two beds of claystone (upper and lower), each has different thickness. The total area of the upper industrial bed occupies an area of approximately $576 \times 10^{6} \mathrm{~m}^{2}$ (Table 1). It has been shown in all sections (Fig. 5 a) with different thicknesses between $1.0 \mathrm{~m}$ (in section H10) to $4.5 \mathrm{~m}$ (in sections TS2, TS4 and TS5), with an average of about $3.16 \mathrm{~m}$. The lower industrial bed has been disappeared at four sections (H7, H9 and H10), and appears in fourteen sections, within Injana Formation (Fig. $5 \mathrm{~b}$ ). The total area of the lower industrial bed is about $453614 \times 10^{3} \mathrm{~m}^{2}$. The thickness of the lower claystone bed ranges from $2.0 \mathrm{~m}$ (in sections H1, TN1 and TN2) to $4.0 \mathrm{~m}$ (in sections TN5, TS1 and TS2), with an average of about $2.7 \mathrm{~m}$. 


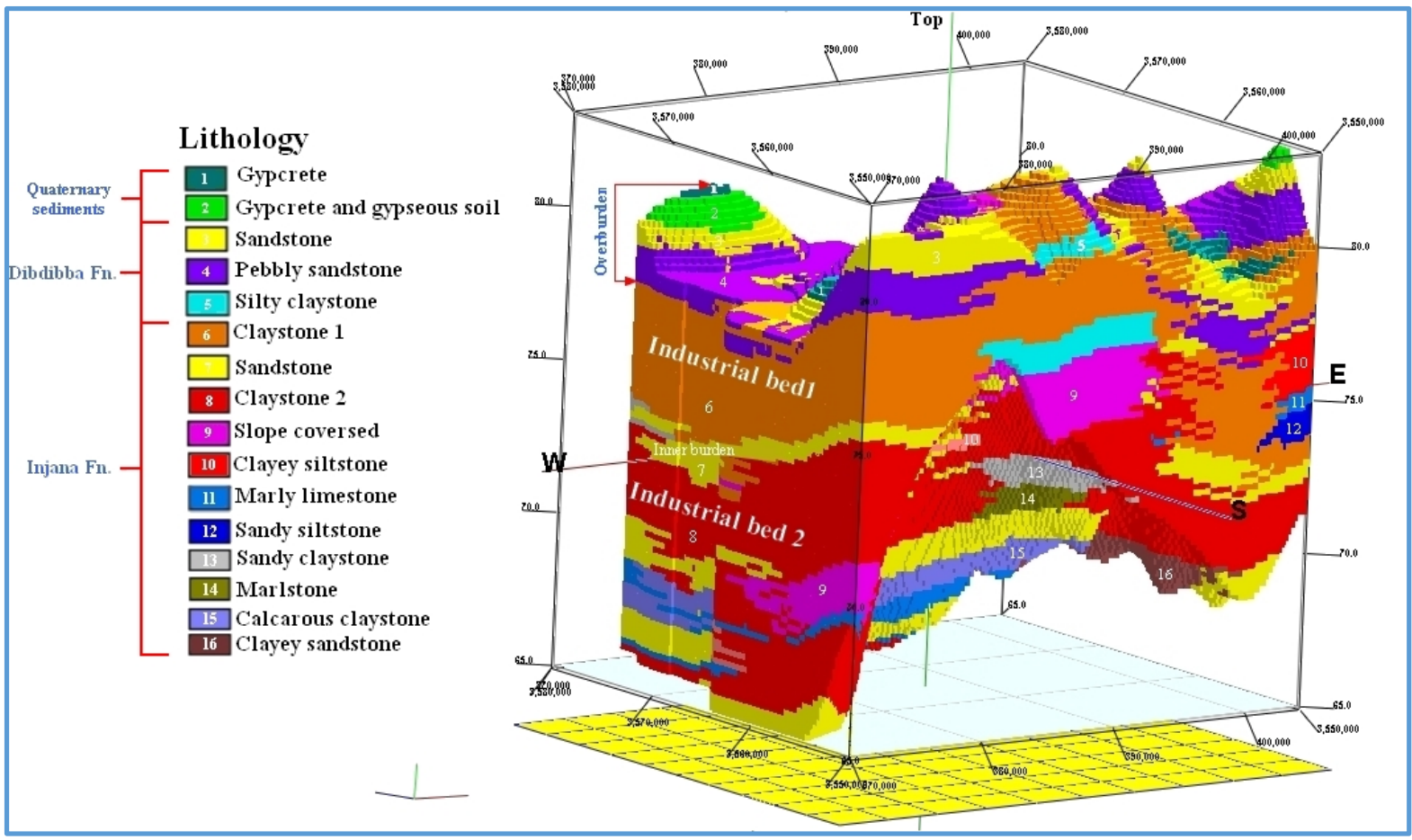

Fig. 4. Stereo-succession of the industrial and overburden in the study area

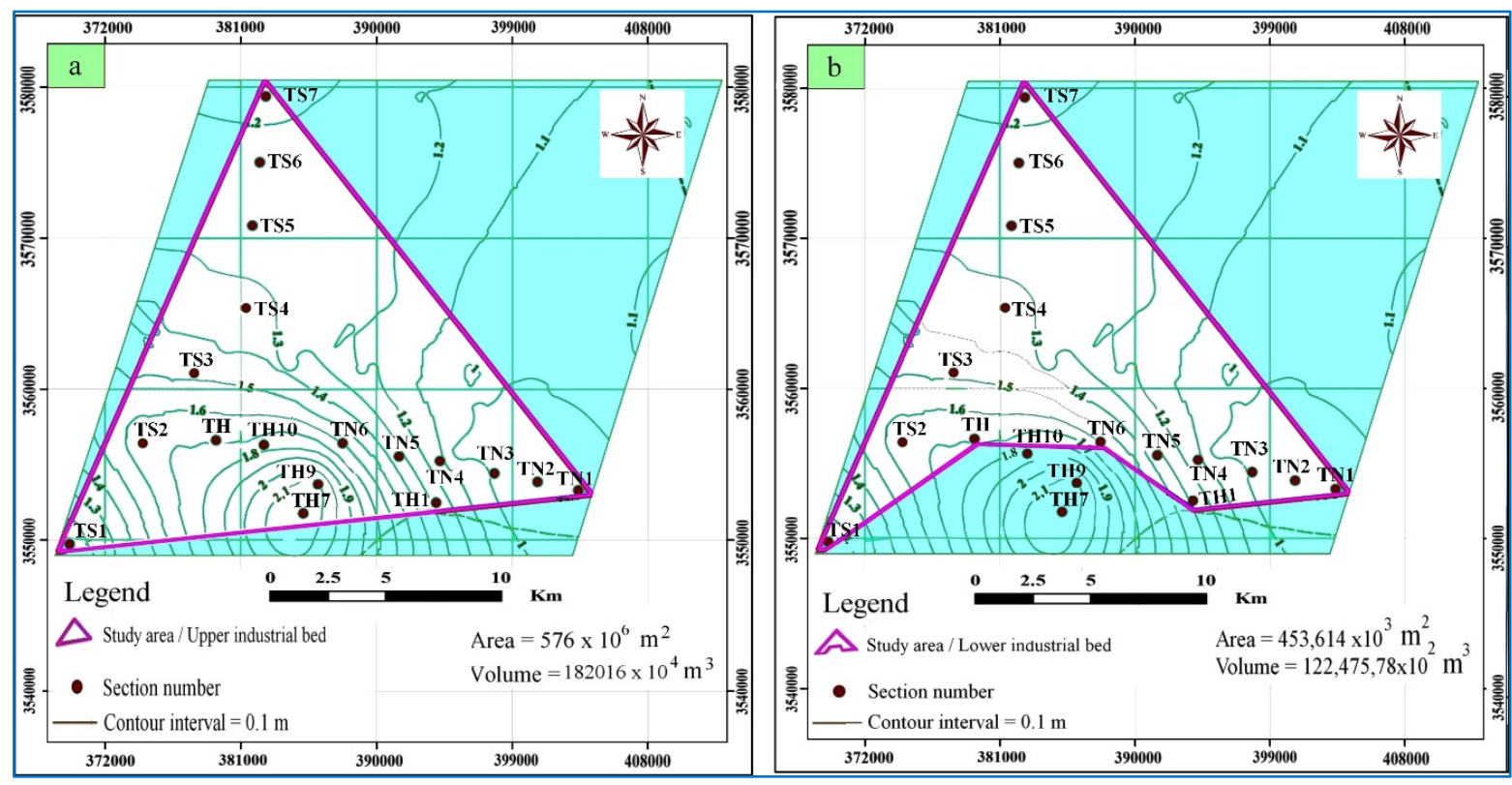

Fig. 5. Location map showing the area showing a) upper industrial bed; b) lower industrial bed 
The total surface area for the both industrial beds was calculated based on the GIS method and found $1,029,614 \times 10^{3} \mathrm{~m}^{2}$. This method was used due to its high accuracy. The surface area, thickness, and volume of the two industrial beds are listed in Table 1. The following equations were used for calculating the volume of the industrial beds in the study area based on GIS method.

$\mathrm{V}$ of (UIB) $\left(\mathrm{m}^{3}\right)=$ Total A $x$ Av thickness of (UIB)

$\mathrm{V}$ of (LIB) $\left(\mathrm{m}^{3}\right)=$ Total A $x$ Av thickness of (LIB)

Where:

$\mathrm{V}$ : volume, A: area, UIB: upper industrial bed, LIB: lower industrial bed, Av: average.

$\mathrm{V}$ of $(\mathrm{UIB})\left(\mathrm{m}^{3}\right)=576 \times 10^{6} \mathrm{~m}^{2} \times 3.16 \mathrm{~m} .=182,016 \times 10^{4} \mathrm{~m}^{3}$

$\mathrm{V}$ of $(\mathrm{LIB})\left(\mathrm{m}^{3}\right)=453,614 \times 10^{3} \mathrm{~m}^{2} \times 2.7 \mathrm{~m} .=12,247,578 \times 10^{2} \mathrm{~m}^{3}$

$\mathrm{T}=\mathrm{V} 1+\mathrm{V} 2$

Where:

T: Total volume of two industrial beds, V1: Volume of the upper industrial bed, V2: Volume of the lower industrial bed. Total volume of two industrial beds $=3,044,917,800 \mathrm{~m}^{3}$.

The total reserve by the GIS method for both industrial beds (tonnage) is 5,663,547,108 tons.

While the area in the triangle method is divided into 27 triangles for the upper industrial bed (Fig. 6 a) and 20 triangles for the lower industrial bed (Fig. 6 b).

The total area of 27 triangles of the upper industrial bed is $5,759 \times 10^{5} \mathrm{~m}^{2}$, but for 20 triangles of the lower industrial bed is $453,764,750 \mathrm{~m}^{2}$.

$A(m)^{2}=B+C$

$\mathrm{A}=5,759 \times 10^{5}+453,764,750=1,029,664,750 \mathrm{~m}^{2}$

$\mathrm{ACT}=$ Sum of ACT $/ \mathrm{N}$ (triangles)

Where:

ACT: Average of Corrected Thickness of the industrial bed, N: number of triangles.

The average of corrected thickness of the lower industrial bed is calculated as follows:

$\mathrm{ACT}=81.7 \mathrm{~m} / 27=3.03 \mathrm{~m}$.

While the average of corrected thickness of the upper industrial bed is computed as follows:

$\mathrm{ACT}=52.8 \mathrm{~m} / 20=2.64 \mathrm{~m}$.

The average of bulk density in the study area is equal $1.68\left(\mathrm{~g} / \mathrm{cm}^{3}\right)$ (Table 2). The total area of two industrial bed by the triangle method is $1,029,664,750 \mathrm{~m}^{2}$ and the total volume is $3,047,536,100 \mathrm{~m}^{3}$. The total reserve $(\mathrm{R})$ is a sum of reserve in each the triangle. The total reserve (tonnage) for two industrial beds is 5,694,522,037 tons. Results of reserve calculations depended on the triangle and GIS methods for the upper industrial bed and lower industrial bed are listed in Tables 3. 
Table 1. Thickness, area, and volume of the two industrial beds in the study area

\begin{tabular}{|c|c|c|c|c|c|c|c|c|}
\hline \multirow[b]{2}{*}{$\begin{array}{l}\text { Section } \\
\text { No }\end{array}$} & \multicolumn{2}{|c|}{ UTM-Coordination } & \multicolumn{3}{|c|}{ Upper industrial bed } & \multicolumn{3}{|c|}{ Lower industrial bed } \\
\hline & Easting & Northing & $\begin{array}{c}\text { Thickness } \\
\text { (m) }\end{array}$ & $\begin{array}{c}\text { Area } \\
\left(\mathbf{m}^{2}\right)\end{array}$ & $\begin{array}{c}\text { Volume } \\
\left(\mathbf{m}^{3}\right)\end{array}$ & $\begin{array}{c}\text { Thickness } \\
\text { (m) }\end{array}$ & $\begin{array}{c}\text { Area } \\
\left(\mathbf{m}^{2}\right)\end{array}$ & $\begin{array}{c}\text { Volume } \\
\left(\mathbf{m}^{3}\right)\end{array}$ \\
\hline TS1 & 3568285 & 382918 & 3.5 & \multirow{19}{*}{$\begin{array}{l}\stackrel{8}{0} \\
\frac{x}{x} \\
b \\
i n\end{array}$} & \multirow{19}{*}{$\begin{array}{l}+0 \\
0 \\
x \\
0 \\
0 \\
0 \\
0 \\
0\end{array}$} & 4.0 & \multirow{19}{*}{$\begin{array}{l}3 \\
\tilde{x} \\
\dot{\Xi} \\
\sigma \\
\tilde{n} \\
\tilde{\sigma}\end{array}$} & \multirow{19}{*}{ 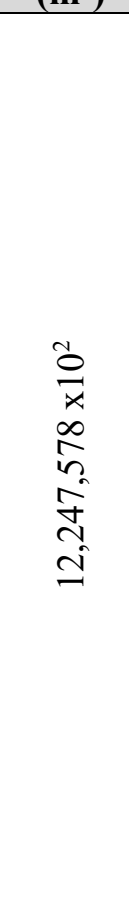 } \\
\hline TS2 & 3573156 & 382196 & 4.5 & & & 4.0 & & \\
\hline TS3 & 3575726 & 382184 & 4.0 & & & 2.5 & & \\
\hline TS4 & 3575729 & 382667 & 4.5 & & & 2.5 & & \\
\hline TS5 & 3580706 & 383293 & 4.5 & & & 3.5 & & \\
\hline TS6 & 3582358 & 382912 & 4.0 & & & 3.5 & & \\
\hline TS7 & 3585219 & 383552 & 3.5 & & & 2.5 & & \\
\hline TN1 & 3553303 & 403400 & 2.5 & & & 2.0 & & \\
\hline TN2 & 3553870 & 400680 & 4.0 & & & 2.0 & & \\
\hline TN3 & 3555169 & 397472 & 3.5 & & & 2.5 & & \\
\hline TN4 & 3555245 & 394204 & 3.5 & & & 2.5 & & \\
\hline TN5 & 3555563 & 391485 & 2.5 & & & 4.0 & & \\
\hline TN6 & 3558166 & 388999 & 3.5 & & & 2.5 & & \\
\hline $\mathrm{TH}$ & 3562131 & 384540 & 2.0 & & & 1.0 & & \\
\hline TH1 & 3552768 & 393702 & 2.5 & & & 2.0 & & \\
\hline TH7 & 3553675 & 381646 & 2.0 & & & - & & \\
\hline TH9 & 3555036 & 384772 & 1.5 & & & - & & \\
\hline TH10 & 3553995 & 388869 & 1.0 & & & - & & \\
\hline Av. & & & 3.16 & & & 2.7 & & \\
\hline
\end{tabular}

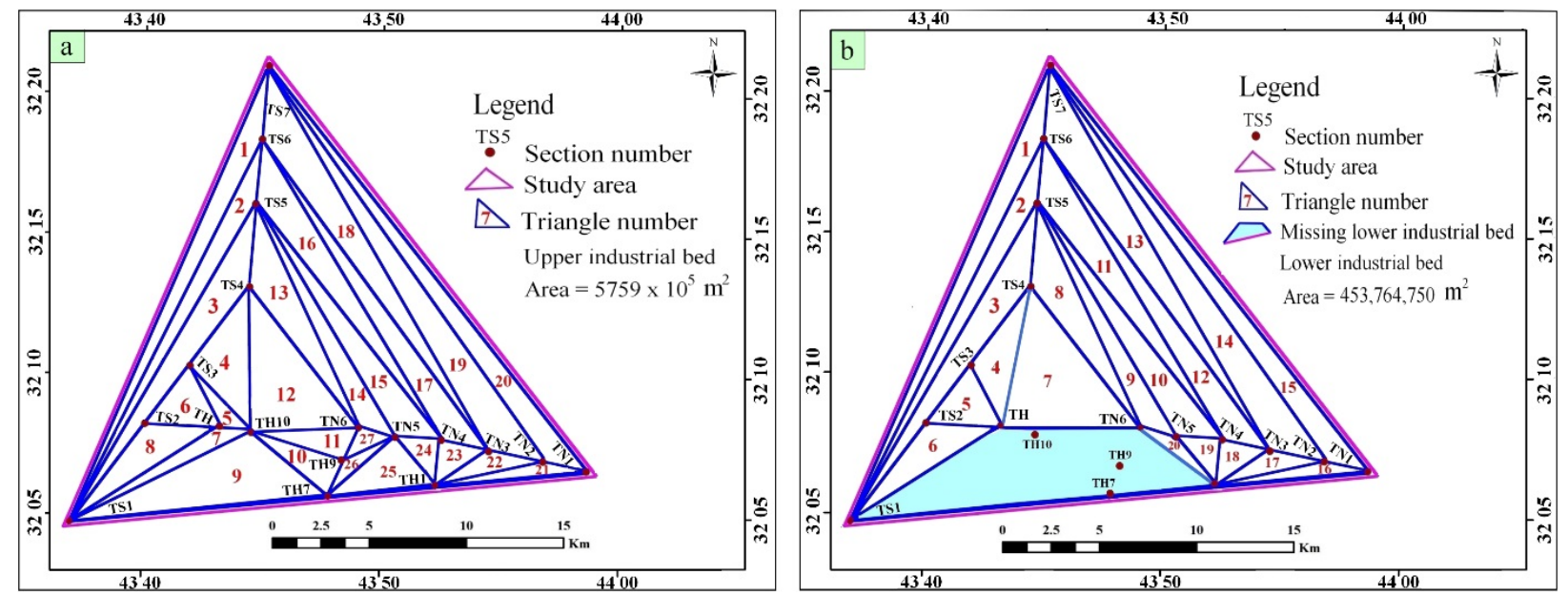

Fig. 6. Reserve calculation based on the triangles method for a) upper industrial bed; b) lower industrial bed

\section{Quantitative Evaluation of The Overburden and Inner Burden}

The overburden occupies an area of approximately $573 \times 10^{6} \mathrm{~m}^{2}$ (Table 2) out of the total area of $576 \times 10^{6} \mathrm{~m}^{2}$, while the remaining area is exposed without overburden (Fig. 7). The inner burden is covering an area about $4,536 \times 10^{5} \mathrm{~m}^{2}$ from the total area of $576 \times 10^{6} \mathrm{~m}^{2}$. The thickness of overburden changes from place to place ranging between $1.0-3.5 \mathrm{~m}$, with an average of about $1.78 \mathrm{~m}$. 
Table 2. Results of physical tests for selected claystone samples

\begin{tabular}{|c|c|c|c|}
\hline \multirow{2}{*}{$\begin{array}{l}\text { Sample } \\
\text { No. }\end{array}$} & \multirow{2}{*}{$\begin{array}{c}\text { Bulk } \\
\text { density } \\
\left(\mathrm{gm} / \mathrm{cm}^{3}\right)\end{array}$} & \multicolumn{2}{|c|}{ Compressive strength } \\
\hline & & $\left(\mathrm{Kg} / \mathrm{cm}^{2}\right)$ & $\left(\mathrm{KN} / \mathbf{m}^{2}\right)$ \\
\hline TS1-1 & 1.57 & 104 & 25.6 \\
\hline TS2-1 & 1.65 & 204 & 49.9 \\
\hline TS3-1 & 2.11 & 113 & 27.6 \\
\hline TS4-1 & 1.95 & 183 & 44.8 \\
\hline TS5-1 & 1.65 & 150 & 36.7 \\
\hline TS6-1 & 1.63 & 167 & 40.9 \\
\hline TS7-1 & 1.88 & 123 & 30.1 \\
\hline TN2-2 & 1.86 & 165 & 40.4 \\
\hline TN3-2 & 1.22 & 118 & 28.9 \\
\hline TN5-2 & 1.64 & 225 & 55.2 \\
\hline TN6-1 & 1.85 & 181 & 44.3 \\
\hline $\mathrm{H} 7-1$ & 1.21 & 127 & 31.1 \\
\hline Average & 1.68 & 154 & 37.9 \\
\hline
\end{tabular}

Table 3. Thickness, area and volume of overburden and inner burden beds in the study are

\begin{tabular}{|c|c|c|c|c|c|c|}
\hline $\begin{array}{l}\text { Section } \\
\text { No } \\
\end{array}$ & $\begin{array}{c}* \text { OT } \\
\text { (m) }\end{array}$ & $\begin{array}{c}\text { Area } \\
\left(\mathbf{m}^{2}\right)\end{array}$ & $\underset{\left(\mathbf{m}^{3}\right)}{\text { Volume }}$ & $\begin{array}{l}* I T \\
\text { (m) }\end{array}$ & $\begin{array}{c}\text { Area } \\
\left(\mathbf{m}^{2}\right)\end{array}$ & $\underset{\left(\mathrm{m}^{3}\right)}{\text { Volume }}$ \\
\hline TS1 & 3.5 & \multirow{19}{*}{$\begin{array}{l}\stackrel{8}{\circ} \\
\stackrel{x}{\check{n}} \\
i n\end{array}$} & \multirow{19}{*}{ 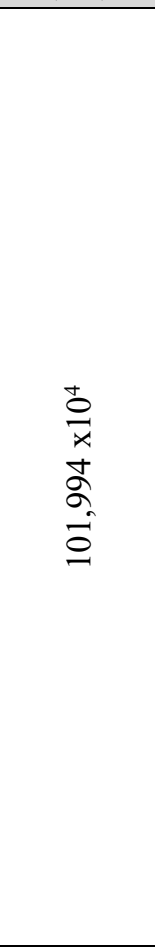 } & 0.75 & \multirow{19}{*}{$\begin{array}{l}n \\
\tilde{x} \\
0 \\
\tilde{n} \\
\tilde{f} \\
f\end{array}$} & \multirow{19}{*}{ 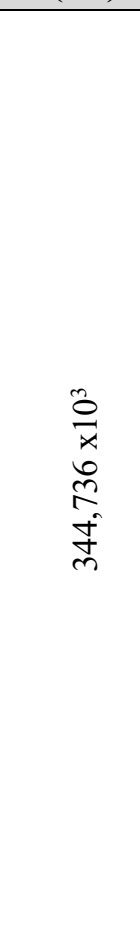 } \\
\hline TS2 & 2.0 & & & 3.0 & & \\
\hline TS3 & 3.25 & & & 1.5 & & \\
\hline TS4 & 2.0 & & & 1.5 & & \\
\hline TS5 & 2.0 & & & 1.0 & & \\
\hline TS6 & 1.5 & & & 1.5 & & \\
\hline TS7 & 2.5 & & & 1.0 & & \\
\hline TN1 & 2.5 & & & 0.5 & & \\
\hline TN2 & 1.8 & & & 0.75 & & \\
\hline TN3 & 3.25 & & & 1.0 & & \\
\hline TN4 & 2.5 & & & 0.75 & & \\
\hline TN5 & 2.0 & & & 1.0 & & \\
\hline TN6 & 1.5 & & & 0.5 & & \\
\hline $\mathrm{H}$ & 1.0 & & & - & & \\
\hline $\mathrm{H} 1$ & - & & & - & & \\
\hline H7 & - & & & - & & \\
\hline H9 & - & & & - & & \\
\hline $\mathrm{H} 10$ & 1.0 & & & - & & \\
\hline Av. & 1.78 & & & 0.76 & & \\
\hline
\end{tabular}

*OT: overburden thickness; *IT: inner burden thickness

In the study area, the inner burden disappears from five sections (TH, TH1, TH7, TH9 and TH10) and appears in thirteen sections in between the two industrial beds of Injana Formation. The thickness of the inner burden ranges from 0.5 to $3.0 \mathrm{~m}$, with average of about 
$0.76 \mathrm{~m}$. The surface area, thickness and volume of overburden and inner burden are computed and listed in Table 2. The surface area of overburden and inner burden were computed by using the GIS method. To calculate the volume of overburden and inner burden in the study area, the equations in below is use as follows.

$\mathrm{V}$ of $(\mathrm{OB})\left(\mathrm{m}^{3}\right)=$ Total A $\mathrm{x}$ Av thickness of $(\mathrm{OB})$

$\mathrm{V}$ of $(\mathrm{IB})\left(\mathrm{m}^{3}\right)=$ Total A $\mathrm{x}$ Av thickness of (IB)

Where:

$\mathrm{V}$ : volume, A: area, OB: overburden, IB: inner burden, Av: average

$\mathrm{V}$ of $(\mathrm{OB})\left(\mathrm{m}^{3}\right)=573 \times 10^{6} \mathrm{~m}^{2} \times 1.78 \mathrm{~m} .=101,994 \times 10^{4} \mathrm{~m}^{3}$

$\mathrm{V}$ of $(\mathrm{IB})\left(\mathrm{m}^{3}\right)=4,536 \times 10^{5} \mathrm{~m}^{2} \times 0.76 \mathrm{~m} .=344,736 \times 10^{3} \mathrm{~m}^{3}$

Total volume of overburden and inner burden $\left(\mathrm{m}^{3}\right)=$ volume of the overburden $\left(\mathrm{m}^{3}\right)+$ volume of the inner bed $\left(\mathrm{m}^{3}\right)$.

Total volume of overburden and inner burden $=1364676 \times 10^{3} \mathrm{~m}^{3}$

The isopach map of overburden bed (Fig. 8) showed that thicknesses in sections TH, TH7, TH9, TH10, and TN6 in the southwest part is either nonexistent or decreases, where this area is considered the best place for the purpose of investing the industrial beads (claystone beds) for the cement and bricks manufacture. In addition, Fig. 8 shows that there are two locations represented by TN1, TN2 and TN3 sections in the southeastern part, and TS7 section in the northwestern part shows an increase in the thickness of the overburden bed.

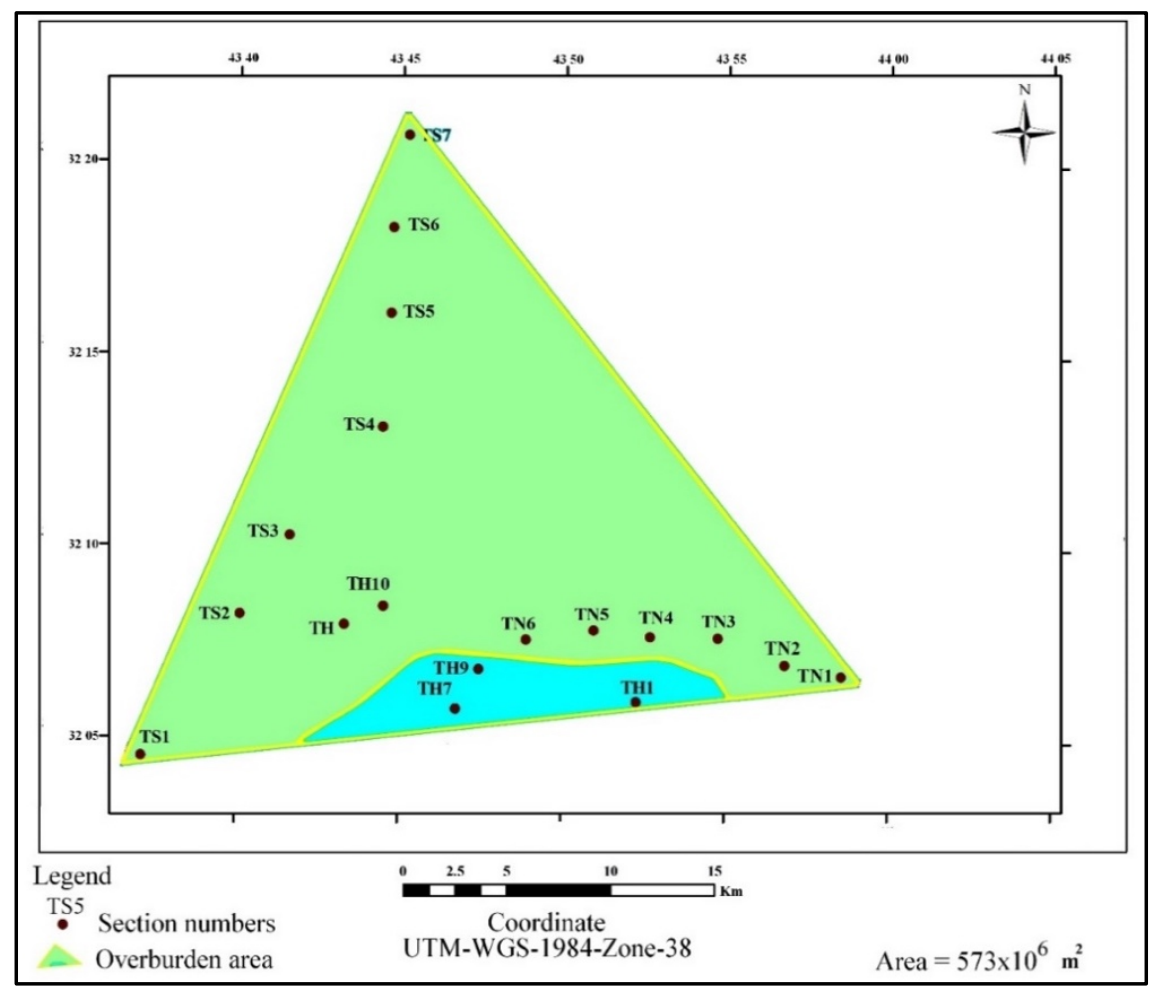

Fig. 7. Location map showing the area of overburden bed 


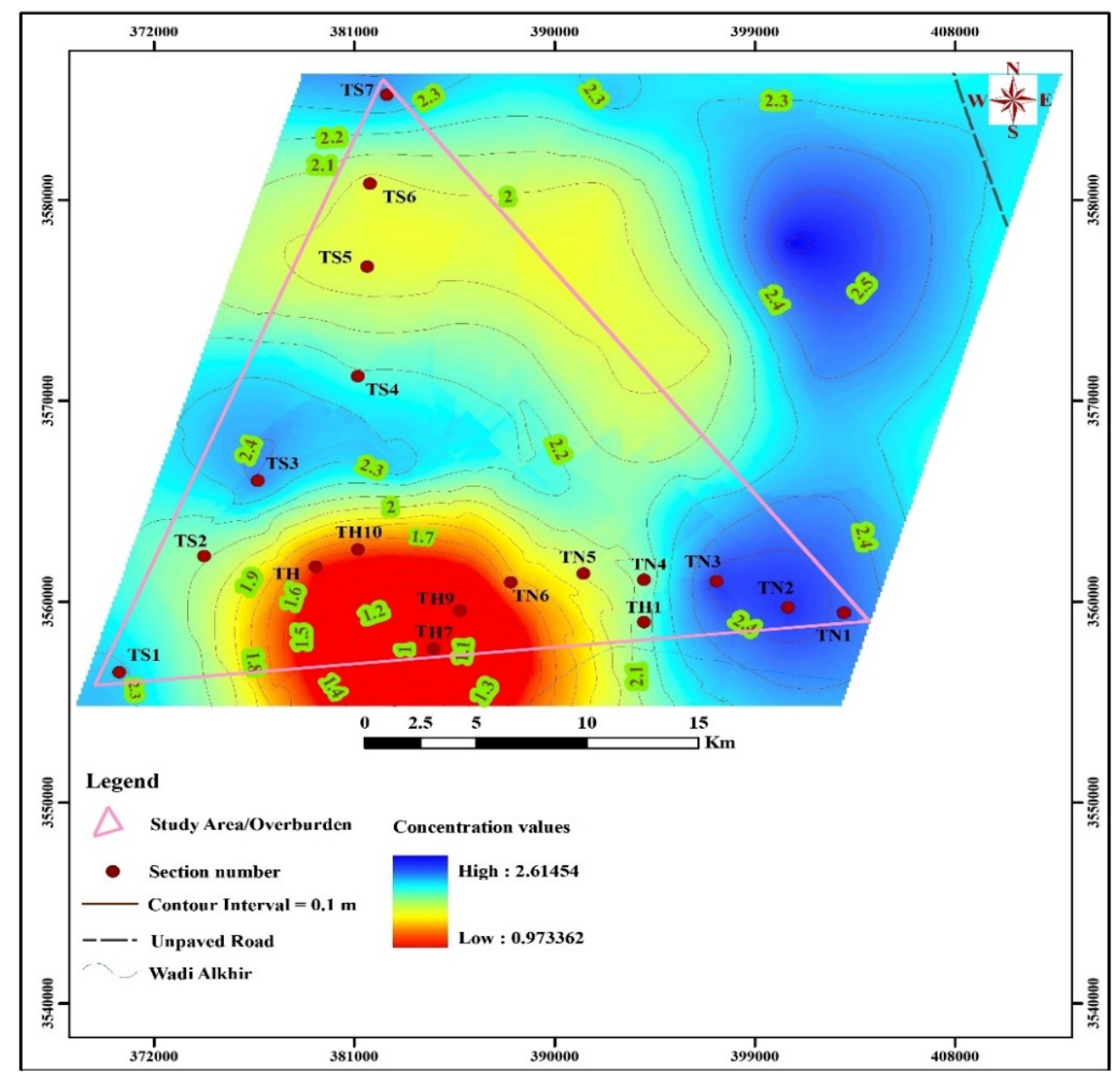

Fig. 8. Isopach map of the overburden bed in the study area

\section{Comparison of Reserve Estimation Methods}

Two methods were used to estimate the reserve of the claystone beds that gave varying results (Table 4). The lowest reserve was 5,663,547,108 tons calculated by the GIS method, while the highest reserve was 5,694,522,037 tons calculated by triangle method.

Table 4. Estimation of reserves in tons calculated in different methods

\begin{tabular}{|c|c|c|c|c|c|c|}
\hline \multicolumn{3}{|c|}{ Method } & $\begin{array}{c}\text { Area } \\
\left(\mathrm{m}^{2}\right)\end{array}$ & $\begin{array}{c}\text { Volume } \\
\left(\mathrm{m}^{3}\right)\end{array}$ & $\begin{array}{c}\text { Reserve } \\
\text { (ton) }\end{array}$ & $\begin{array}{c}\text { Total reserve } \\
\text { (ton) }\end{array}$ \\
\hline \multirow{2}{*}{\multicolumn{2}{|c|}{ GIS }} & UIB & $576 \times 10^{6}$ & $182,016 \times 10^{4}$ & $338,5497,600$ & \multirow{2}{*}{$5,663,547,108$} \\
\hline & & LIB & $453,614 \times 10^{3}$ & $1,224,757,800$ & $2,278,049,508$ & \\
\hline \multirow{2}{*}{ Block } & \multirow{2}{*}{ Triangle } & UIB & $5,759 \times 10^{5}$ & $1,822,371,275$ & $3,389,610,572$ & \multirow{2}{*}{$5,694,522,037$} \\
\hline & & LIB & $453,764,750$ & $1,225,164,825$ & $2,304,911,465$ & \\
\hline
\end{tabular}

UIB: Upper industrial bed; LIB: Lower industrial bed

The GIS and triangles methods were more accurate than other traditional methods. The difference percent between GIS and triangles methods is $(0.085 \%)$ which computed by the equation below: 
Difference percent $=\frac{\text { V.in triangle method-V.in GIS method }}{\text { V.in GIS method }}$

Difference percent $=\frac{3047536100-3,044,917,800}{3,044,917,800}=0.085 \%$

This difference $(0.085 \%)$ of the tonnage is considered unimportant and ineffective.

\section{DISCUSSION}

The claystone reserve quantities were estimated by comparing the chemical results of the claystone with those of Shah and Ali (2007) they determined the acceptable oxides limits $(\mathrm{CaO}$ is $17.08, \mathrm{MgO}$ is $3.8, \mathrm{SiO}_{2}$ is $50.3, \mathrm{Al}_{2} \mathrm{O}_{3}$ is $19.2, \mathrm{Fe}_{2} \mathrm{O}_{3}$ is $6.08, \mathrm{Na}_{2} \mathrm{O}$ is 1.5 and $\mathrm{K}_{2} \mathrm{O}$ is $1.2 \%$ ) for the industrial bed suitable for the cement industry. The geochemical and mineralogical data are used to assess the deposition of the shales from the Beduh (L. Triassic) and Baluti (U. Triassic) formations at the North of Iraq (Tobia et al., 2017). The chemical results of the claystone were also compared to the acceptable limits $\left(\mathrm{CaO}\right.$ is $17.08, \mathrm{MgO}$ is $6.0, \mathrm{SiO}_{2}$ is 40.4 , $\mathrm{Al}_{2} \mathrm{O}_{3}$ is $10.3, \mathrm{Fe}_{2} \mathrm{O}_{3}$ is 6.5 , $\mathrm{LOI}$ is $17, \mathrm{Na} 2 \mathrm{O}$ is 0.8 and $\mathrm{K}_{2} \mathrm{O}$ is 2.3) stated by Al-Qazaz et al., (2005) in terms of brick industry. The average content of claystone samples are composed of $\mathrm{SiO} 2$ (40.9\%), $\mathrm{A} 2 \mathrm{O} 3$ (9.1\%), Fe2O3 (5.6\%), CaO (17.1\%), MgO (5.2\%), K2O (1.6\%), Na2O (1.7\%), TiO2 (0.77\%), MnO (0.09\%), LOI (16.1\%), $\mathrm{Cl}(0.8 \%)$, and SO3 (0.6\%). The proved amount of claystone reserve as an industrial bed for cement and brick industry is estimated of about $5,695,704 \times 10^{3}$ tons. The reserve of claystone in the study area is available to be increased by further work includes geological studies such as increasing the number of geological sections and wells in the center of the plateau due to its lack of exposed rock. The overburden consisting of sandstone of Dibdibba Formation can also be invested for further industries due to its mineral content. The estimated reserve of claystone by this study is enough to cover the requirements of cement and brick factories and encourage to establish new factories in the Najaf and Karbala provinces. The claystone is basically as $100 \%$ for the ordinary and perforated bricks making, but only $28 \%$ of the total mixture as a raw material to kiln feed for the cement industry. As usual, the amount of claystone consumed (ton per year) is depended on the annual design capacity of cement and brick plants. This is equivalent to 900,000 tons per year of clay for Najaf Cement Factory only, in addition to an estimated of 600,000 tons per year of clay for only one brick plant. The huge reserve is expected will be enough to supply raw material for cement and brick factories for long time to a forthcoming future. This study is used claystone as an alternative material than the recent clay. Claystone supplies the silica, alumina, and ferrite to the cement mixture. The claystone reserve in the study area is considered as $\mathrm{C} 1$ class based on the Russian system. The Russian system is preferred and is commonly used in the Iraqi Geological Survey work context. The reserve estimation methods used in this study depended on the interpolation point within the boundary of the investigated area as shown below: 
1. Block method contain triangle and polygon

2. GIS method

The triangle method is more accurate than the polygon method due it has depending on more results of chemical components. On the other hand, the GIS method is of high-accuracy in computing area and volume of the claystone bed.

The claystone bed is characterized by medium tough, so it is possible to use hydraulic excavators without using the explosives during the mining, in particularly the extraction of claystone bed. This achievement is of great economic importance to avoid the high cost resulting from the use of explosives during mining work. The other advantage is coming from the low hardness of claystone bed that will be easy for milling and eventually help in reducing the electric power consumption. Finally, the total price of the final product will be of less cost.

\section{CONCLUSIONS}

Many findings have been drawn from this study:

1. A new resource of raw materials (claystone) suitable for the cement and brick industry has been determined as a proven reserve by using the triangle and GIS methods.

2. The calculated reserve by the GIS method was estimated to be $5,663,547,108$ tons, whereas it was estimated by triangle method to be 5,694,522,037 tons based on Russian system (C1 category).

3. The stripping ratio (0.3), low toughness, average value of compressive strength e (154 $\left.\mathrm{Kg} / \mathrm{cm}^{2}\right)$ and bulk density $\left(1.68 \mathrm{gm} / \mathrm{cm}^{3}\right)$ are of economic significance, where they serve the mining works and eventually leading to reduce the final cost of the production.

\section{ACKNOWLEDGEMENTS}

The authors thank the Adviser Office of Development Affairs at the Ministry of Industry and Minerals for their approval this subject as a $\mathrm{PhD}$ project. Our thanks also go to the staff of Iraq Geological Survey (Information Department) for providing us with the necessary geological maps of the study area.

\section{REFRENCES}

Al-Atia, M. J., 2001. Evaluation of Mineral Deposits, Practices in Economic Geology. GEOSURV, Iraq. 157P. Al-Auweidy, M. R., 2013. Qualitative, quantitative and radiological assessment of marl layer in the Euphrates Formation for Portland cement industry in Kufa cement quarry at Al-Najaf Governorate. Published M.Sc. thesis, College of Science, University of Baghdad.

Al-Bassam, K. S., and Al-Khafaji, A. A., 2012. Minerals prospecting and exploration, work procedures No. WP-29- PART 14. Report No. 1995. GEOSURV, Iraq.

Ali, K. K., Awadh, S. M., and Al-Auweidy, M. R., 2014. Assessment natural radioactivity of marl as raw material at Kufa Cement Quarry in Najaf Governorate. Iraqi Journal of Science, 55(2A):454-462. 
Al-Qazaz, D., Boles, Q. M., Jabori, W. M., and Noor Al-Dein, S. H., 2005. Reevaluation of the soil suitable for mud industry, Al-Sowera brick factory. The State Company of Geological Survey and Mining. Internal report (Arabic). p 18.

Awadh, S. M., and Abdullah, H. H., 2011. Mineralogical, geochemical, and geotechnical evaluation of Al-Sowera soil for the building brick industry in Iraq. Arab J Geosci, 4:413-419.

Carranza, E. J. M., 2009. Geochemical Anomaly and Mineral Prospectively Mapping in GIS. Handbook if Exploration and Environmental Geochemistry 11. Elsevier, UK, $351 \mathrm{P}$.

Haldar, S. K., 2018. Mineral Exploration (Second Edition) Principles and Applications, Handbook, Pages 69-84. https://doi.org/10.1016/B978-0-12-814022-2.00004-6. Published by Elsevier.

Janipella, R., Gupta, V., and Moharir, R. V., 2019. Current Developments in Biotechnology and Bioengineering. Application of Geographic Information System in Energy Utilization. Journal of Science Direct, 143-161.

Kreiter, V. M., 1968. Geological Prospecting and Exploration. Mir Publishers, Moscow, Russia. 385P.

Mendelsohn, F., 1980. Some aspects of ore reserve estimation. Book of economic geology research unit. University of the Witwatersrand Johannesburg. p.47.

Moon, C. J., Whateley, M. K. G., and Evans, A. M., 2006: Introduction to Mineral Exploration. 2nd ed., Blackwell Publishing. USA. 499P.

Partington, G. A., 2010. Exploration targeting using (GIS): more than a digital light table. AIG 'Geo-Computing, Brisbane, Australia. AIG Bulletin, 51.

Shah, M. T., and Ali, L. F., 2007. Chemical study of the Raw Material in Gandghar Range, District Haripur, NWFP, for Portland Cement Manufacturing. Jour. Chem. Soc. Pak., 29 (2): $103-110$.

Taylor, H. K., 1994: Ore Reserves, Mining and Profit; Can. Inst. Min. Metall. Bull., 87(983): 38-46.

Tobia, F. H., Mustafa, B. H., Shangola, S. S., and Kasha, M. U., 2017. Mineralogical and geochemical comparison between the shales of Beduh and Baluti formations in the northern thrust zone, Kurdistan region, Iraq: implication for provenance and tectonic setting. Iraqi Geological Journal, 1-23.

Wellmer, F. W., Dalheimer, M., and Wagner M., 2008. Economic Evaluations in Exploration. 2nd ed., Springer Berlin, Heidelberg, New York, 263P. 